\title{
Murray River and Big Ben
}

\section{Mitchell Shepherd}

'Hey, where do you live?'

'Clyde Street.'

'Me too.'

'OK.'

'Let's walk home together.'

'OK.'

'What's your name? My name's Ben.'

'Murray.'

Murray's first day of school at Hammond Public was difficult. He entered the second grade midway through the first semester, thrown into a pit of six and seven year olds who had already been allowed time sowing seeds of friendship and understanding the social hierarchy.

'Which class are you in?' asked Ben.

'2D,' replied Murray, still unfamiliar with the new world around him.

' $\mathrm{I}$ ' $\mathrm{m}$ in $2 \mathrm{~W}$, but 2D is still a good class. Mrs Diver is nice.'

'Yeah.'

After each of Murray's short responses, Ben would learn a little more about the new boy; add a new piece to the puzzle.

'Where are you from?'

'Up north.'

'Is that far away?'

'Yeah, pretty far.'

Murray walked in short steps at a fast pace while gazing at the ground a few metres ahead. Ben used this time to watch Murray.

'Why is your skin black?'

'I dunno. It's not really black, but.'

Ben moved closer to Murray and took a closer look at the skin of his arm.

'Yeah, you're right.'

'I think it's more brown than black.' 
Ben glanced once again at Murray's arm.

'Yeah it's brown, not black. Sorry.'

'Doesn't matter. It's just colour.'

The two boys were now well clear of the school grounds. On their way to Clyde Street they would walk through leafy inner city streets, past a newsagent, and down one hill. Murray walked on the edge of the road whereas Ben preferred the lip of the gutter.

'Do you have a footy in your bag?' Ben asked excitedly, noticing an unzipped compartment to Murray's dark blue backpack.

'Yeah.'

'Why didn't ya bring it out at lunchtime?'

'I dunno.'

Murray continued to walk straight, eyes peering at the road in front, but Ben had come close, closer than he was during the inspection of Murray's skin, to get a better look at the football.

'I can get it out if you like,' said Murray.

'Yeah get it out and we can play. Is it a Sherrin?'

'Nah.'

Murray released one arm from the loop of his backpack and swung it around to his front, pulling out the red footy and tossing it to Ben.

'I've seen these balls in the shops, they're good,' said Ben, approvingly. 'What team do ya follow?'

'Stuart Park Snakes A Grade,' said Murray, looking at Ben in a way that displayed his loyalty.

Ben tucked the footy under his arm and gazed blankly into the space ahead, his mind ticking over fiercely.

'Do they play in the AFL?' asked Ben.

'Nah.'

'Do they play on TV?'

'I don't think so.'

'Where do they play?'

'They play up north. They're my home team.'

'Oh,' said Ben. 'Are they good?'

'Yeah they're pretty good.' 
Ben continued tossing the ball from hand to hand now that he had resolved the issue of the mysterious Stuart Park Snakes.

'Who do you go for?' asked Murray.

'Carlton Blues. Do you know them? They play on TV.'

'I think so,' replied Murray.

Ben's face again slipped into a gaze of thought.

'Are you from Africa?' asked Ben.

'No.'

'So where are you from again?'

'Australia.'

A confused silence arose as both boys analysed the misunderstanding. It lasted several moments but was not uncomfortable for either of them.

Murray spoke once more.

'I'm Aboriginal.'

'Is that the same as Indiginal?'

'I think so. Why?'

'Because I think Carlton Blues have Indiginal players.'

'Are they good players?'

'Yeah, they're really fast. They run like this...'

Ben bolted off, ball in hand, demonstrating astonishing acceleration and agility. He ran for probably ten metres before stopping and waiting for Murray to catch up.

'See how fast they are?' asked Ben.

'Yeah that was fast,' said Murray.

'Maybe you should play for Carlton Blues.'

'Yeah, I might.'

The boys continued on their way home to Clyde Street. Ben's curiosity had begun to subside and Murray was feeling more comfortable. Murray however kept thinking about tomorrow, which would be filled with stares, whispers and loneliness. He thought of his first week at the previous school he'd attended. If it was going to be the same here, things would get worse before they got better. But competing with these thoughts was the young man walking beside him. He liked Ben and he thought of it as an added bonus that they lived in the same street. 
'Do you like your name?' asked Ben.

Murray paused for a moment, unsure of the answer to the question he, until now, had never been asked.

'Yeah I do. I like my name because there is a river named after me.'

'Which one?'

'It's called Murray River.'

This impressed Ben as he bounced the ball in front of him.

'My dad said there is a clock somewhere called Ben,' said Ben, revealing a competitive streak, which quickly turned into acknowledged defeat. 'But a clock isn't as good as a river.'

Murray had forgotten to wear his hat to school, so he continually brushed his long wavy dark hair from his eyes. Although Ben had been watching this from the beginning of their walk, it only now caught his attention.

'Hey I'll tell you what we should do, we should go to school one day wearing wigs,' said Ben enthusiastically.

'What for?' replied Murray.

'I should wear a wig with your type of hair, and you should wear a wig with blonde hair like mine. People will think that we have swapped hair,' said Ben before cackling hysterically, dropping the football as he laughed.

Murray smiled, not so much at the joke, but more at Ben's reaction.

'We could wear name tags too,' said Murray, continuing the joke for Ben's sake. 'I could wear one saying Ben, and you wear one saying Murray.'

Ben, having only quietened to hear Murray's words, burst into laughter once again. Ben's laugh was proper and real; there was nothing fake about it.

After the joke burnt out, Ben passed the ball to Murray with an AFL style hand-pass. Murray returned the ball in the same fashion. It was a language they both spoke easily.

Murray looked at Ben and spoke.

'Do you know how you asked me why I didn't have my footy out at lunch?' 
'Yeah.'

'Well I did have my footy out at lunch.'

'Did everyone want to play with it?'

'No.'

'Did anyone?'

'No one asked me.'

Ben was amazed at Murray's confession. Not many people brought good quality footballs to school and he was convinced that his school mates would have wanted to play with it. He arrived at the only possible conclusion.

'Well no one must have seen you Murray because it's a good footy and people loving playing with them.'

Murray thought about it for a few moments before responding.

'Then I guess no one saw me.'

The boys turned into Clyde Street, both growing curious as to where the other lived.

'But I'll see you tomorrow Murray, you don't have to worry about that.' 'OK.'

They approached Ben's house first as it sat near the beginning of the street. 'This is my house, number six,' said Ben proudly. 'What number are you?' 'I think my house is number forty-five, it's down the bottom,' said Murray. 'Well I have pizza on Monday nights,' said Ben. 'Do you like pizza?' 'Yeah I do.'

'I'll ask my mum if you can come over and have pizza with us one night.' 'OK.'

'I'm going inside, see ya tomorrow. Bring ya footy.'

'OK.'

'We can talk again tomorrow,' said Ben, before jogging off inside. Murray watched him run up the stairs of his front porch and disappear inside. Murray then walked off down the hill and towards his new home, tossing the ball from hand to hand. 